\title{
LEARNING STRATEGIES FOR SLOW LEARNERS USING THE PROJECT BASED LEARNING MODEL IN PRIMARY SCHOOL
}

\author{
Ayu Hartini
}

S-2 Basic Education, State University of Surabaya, ayuhartini.new @ gmail.com

\section{Dessy Widyaningtyas}

S-2 Basic Education, State University of Surabaya, dessywidya213@gmail.com

\section{Mai Istiqomatul Mashluhah}

S-2 Basic Education, State University of Surabaya, maiistiqomatulmashluhah@gmail.com

\begin{abstract}
Children with slow learning problem or a slow learner are those who have low learning achievement or slightly below average of children in general. Today, the children slowly learn many encountered not only in school inclusion, but in regular schools too. Teachers who do not have adequate experience will find it difficult to deal with in the classroom. So the goal of this research is to find appropriate learning strategies for slow learners in elementary school.
\end{abstract}

Keywords: slow learners, project based learning model

\section{INTRODUCTION}

Education is the right of all people, both children, adolescents, and adults, both men and women, normal children and children with special needs. Everyone has the right to develop the potential of humanity to be fully human through education. This is consistent with the concept of education for all (education for all).

Education for all can be achieved by organizing inclusive education in early childhood education (PAUD), primary education (SD / MI and SMP / MTS), secondary education (high school / MA and SMK / MAK), and higher education. Inclusive education is an education system that accommodates all children, both normal children and children with special needs in regular schools, with different characteristics, development, and the need for children to develop children's potential optimally. The Salamanca Statement and Framework for Action on Special Needs Education Article 2 (Sue Stubbs, 2002: 123) states that the regular school-oriented inclusive is the most effective institution to tackle discrimination, creating welcoming communities, building an inclusive society and achieving education for all.

Based on Minister of National Education Republic of Indonesia No. 70 Year 2009 on Inclusive Education For Students Who Have and Have Potential Intelligence abnormalities and / or the Special Talent, students including children with special needs include: 1) children with visual 
impairments; 2) children with hearing impairment; 3) children with speech impairment; 4) children with intellectual challenges; 5) children with physical disabilities; 6) children with behavioral impairment; 7) children learning disabilities; 8) children slow learner (slow learners); 9) children with autism; 10) children with motor disorders; 11) children who are victims of drug abuse, illegal drugs and other addictive substances; 12) children with other disorders; and 13) children with double impairment.

Children slow learner or slow learners is one of the special needs children who require special education services in school inclusion. Special education services are needed for children slowly learn to face some learning problems, such as: 1) difficulty understanding abstract concepts; 2) have a limited vocabulary; 3 ) has a low learning motivation; 4) require more time to understand a material than a normal child of his age; and 5) requires repetition in the explanation of the material.

Slow learner child can almost be found in every school inclusion. Ana Lisdiana (2012: 1) revealed that approximately $14.1 \%$ of children, including children slow learner. This amount is more than the total number of children learning disabilities, retarded children, and children with autism. Based on data from Ministry of Social Affairs of the Republic of Indonesia (in Yachya Hasyim, 2013: 113), in 2011 the number of children with special needs in Indonesia reached more than 7 million people, or about $3 \%$ of the total amount of the entire population of Indonesia. Of these, the majority including slow learner child, autism, and mental retardation.

Although their numbers are high enough, the presence of children slow learner in the class received less attention because of the obstacles include barriers that can not be observed directly. Slow learner child has no physical difference with other normal children. Barriers slow learner child will be looked after following the learning process. Thus, many children encountered slow learner who attend public schools, not in the school inclusion. This is due to the characteristics of children slowly learn can't be observed by naked eye, as well as lack of awareness of parents still consider the child slow learner as a disgrace and they are reluctant to send their children to school inclusion because they feel that their child is normal.

High prevalence and its existence can not be identified directly demanded regular teachers (class teachers and subject teachers) to have arrangements related to the presence of children slowly learn in the classroom. However, in some inclusive schools, preparation of regular teachers to deal with children's learning and special education is not optimal slow learner. This is understandable because, in general, regular teachers do not learn about special education in depth and have not been trained in collaborative competencies and specialized competencies related penguasaaan child's special education services slow learner. Similarly, teachers in public schools, where children may be 
slow to learn not to be rejected but in the competence of the teachers have not had a child learning related provision slow learner who is placed in a class with students of normal.

In addition, in reality regular teachers have to face some problems in the learning process in schools. Based on the research results Sunardi (in Sunaryo, 2009: 10), in general, problems can be identified related to the learning process at the school include: 1) the learning process has not been implemented in the form of teamteaching;2) teachers tend to have difficulty in formulating a flexible curriculum, preparation of Individualized Education Program (PPI), and the development objectives, materials, and methods of learning; 3) an error occurs in practice where the curriculum targets children with special needs together with normal children and there is a presumption of children with certain barriers (physical, emotional, social, or intellectual) does not have sufficient ability to master the learning material; 4) learning not to use the media, resources, and learning environment that vary according to the needs of children with special needs due to limited school facilities; 5) using a scoring system yet flexible and varied approach because there are no clear guidelines on the assessment system; and 6) there is still a view that the system of assessment of learning outcomes of children with special needs together with other normal children.

Prevalence is high enough, its existence is the lack of attention, lack of preparation of regular teachers in dealing with learning and special education for children slowly learn, and some of the problems related to the learning process in schools caused many children slow learner who has not been able to overcome the problem of learning and achieve learning objectives optimally. Thus, the potential they have not developed optimally.

One of the components that are important to address learning problems and help achieve learning goals optimally slow learner child, according to their potential is learning strategy. Learning strategies play an important role in providing convenience in the child's learning process slow learner, so that learning objectives can be achieved effectively and efficiently. At school inclusion, regular teachers can cooperate with the Special Supervising Teacher (GPK) for selecting, designing, and implementing appropriate learning strategies for children slow learner. While in the public schools, teachers can work together in team teaching with the selection of appropriate learning models.

Appropriate learning strategies for children is a slow learner learning strategies in accordance with the child's ability to learn slowly. In accordance with the opinion Hidayat (2009: 5) on instructional strategies for all children, appropriate learning strategies for children slowly learn can be applied to adjust a child's learning abilities slow learner with the purpose, time, rewards, tasks, and aid in the learning process. This is related to the five components of learning strategies proposed by 
Walter Dick and Carrey (in B. Uno and Nurdin Hamzah Mohamad 2011: 21), including: 1) the introduction of learning activities; 2) delivery of information; 3) student participation; 4) assessment of learning; and 5) follow-up activities. Each teacher in elementary school can develop the five components of learning strategies to address children's learning problems slow learner, so that the goal can be achieved at an optimal learning, effective, and efficient.

\section{CHARACTERISTICS OF SLOW LEARNERS}

Children learn sluggish known as slowlearners, backward, dull,or borderline. Slow child learns differently than children who have mental retardation, underachiever, children or learning disabilities (learning disabled). Some experts identify children slowly learn based on the level of intelligence or IQ test results.

Cooter, Cooter Jr., and Wiley (in Nani Triani and Amir, 2013: 3) explains that the child is a slow learner child who has a low learning achievement or slightly below normal average child at one or all academic areas and have a score IQ between 70 and 90 .

Mumpuniarti (2007: 14) identifies slow learner child as a child who has an IQ between 70 and 89. Based on the Wechsler intelligence scale (in Sugihartono, et al., 2007: 41), children with an IQ of 70 to 89 including borderline (70-79) and a low average or dull (80-89).

Burt (in GL Reddy, R. Ramar, and A. Kusuma, 2006: 2) explains that the term backward or slow learners are given to children who can not do the work that should be done by his age. Jenson (GL Reddy, R. Ramar, and A. Kusuma, 2006: 2) added, the slow learner child with an IQ of 80 to 90 slower in grasping the subject matter associated with symbols, abstract or conceptual material. Most children slow learner having problems in reading and math.

The level of intelligence or IQ test results slow learner child is closely related to the intellectual development of children. Judging from the development of intellectual, Pichla, Gracey, and Currie (2006: 39) argues that the slow learner child, including children who have cognitive impairment (cognitive impairment). Children with cognitive deficits require additional repetitions to learn a new skill or knowledge, but they can learn and participate in a public school with the aid and certain modifications. Children with cognitive impairment may experience concentration problems and talk.

From the description it can be concluded that the child slow learner or slow learners are children who have developmental delays, mental, and has limited the ability of learning and adjustment because they have an IQ slightly below normal, which is between 70 to 89 , so it takes longer and repeated and over to complete academic assignments and non akademic. 
Some experts pointed out that there are many factors that can cause a slow learner child. GL Reddy, R. Ramar, and A. Kusuma (2006: 11-15) argues that poverty, parental intelligence factor and the number of family members, emotional factors and personal factors (including physical abnormalities, condition of the body are diseased, impaired vision, hearing, and speech, absenteeism in schools and the lack of confidence) are the four factors that cause slow learner child.

Slow learner child has certain characteristics that distinguish it from normal children. GL Reddy, R. Ramar, and A. Kusuma (2006: 6-18) describes four characteristics of children slowly learn, in terms of contributing factors, as follows: 1.) Lack of cognitive capacity includes not managed to resolve the situation of learning and thinking abstract, have difficulty in operating complex thinking, the process of developing the concept or idea underlying generalizations school assignments, particularly language and mathematics, is low, and can not use with both cognitive strategies that are essential for the retention process (GL Reddy, R. Ramar, and A . Kusuma, 2006: 6-7) .; 2.) Memory or low memory due to lack of attention to the information submitted so that the child can not store information in the long term .; 3.) Disruption and lack of concentration, attention span slow learner child is relatively short and low concentration power. Slow learner child can not concentrate on learning verbally delivered more than thirty minutes (GL Reddy, R. Ramar, and A. Kusuma, 2006: 10) .; 4.) The inability to express ideas, they have difficulty in finding and combining words, emotional immaturity and shyness made a slow learner child is not able to express or expresses the idea that children learn more sluggish often use body language rather than spoken language.

In addition, Munawir Yusuf (2005: 111) identifies some of the symptoms or slow learner child characteristics, including: a) the average learning achievement is low, usually less than six; b) often late in completing academic tasks, when compared to their classmates; c) the grasp of the lesson is slow; and d) once lived classes.

Slow learner child experiencing some problems in learning due to causes that can not be observed immediately (unobservable) (Mumpuniarti, 2007: 1). The cause is related to the power of thinking and learning ability. Malik, Rehman and Hanif (2012: 136) in research outlines some of the learning problems of children slowly learn from a variety of sources, including: a) has a learning pace that is slower than a normal child of his age; b) requires more stimulation to perform simple tasks; and c) having problems of adaptation in class because they have ability to do tasks that are lower than their classmates.

In addition to learning problems, slow learning children also face behavioral problems. Problems slow learner child's behavior caused by the limitations of psychological skills, including: 
a) a limited mechanical skills; b) low self-concept; c) an immature interpersonal relationships; d) communication problems; and e) an understanding of the social role that is not appropriate (Malik, Rehman and Hanif, 2012: 136).

From the explanations above, then slow learner problems in this idea is focused on learning problems, consist: 1) have low achievement; 2) have low memory; 3) pay less attention; 4) has a slower learning speed compared to his classmates; 5) require more stimulus to perform simple tasks; and 6) having problems of adaptation and social relations in the classroom.

\section{PROJECT BASED LEARNING MODELS}

Project Based Learning is a learning model that has been developed in developed countries like the United States. More define comprehensively about Project Based Learning by The George Lucas Educational Foundation (2005) are as follows: 1) Project-based learning asks a question or poses a problem that each student can answer, Project Based Learning is a learning model that requires teachers or learners develop guiding questions (a guiding question ). Given that each of these learners have different learning styles, then Project Based Learning provides an opportunity for students to explore the content (matter) using a variety of ways that are meaningful to him, and conduct collaborative experiments. This allows each learner in the end be able to answer questions guiding(The George Lucas Educational Foundational: 2005);2) Project-based learning asks students to investigate issues and topics addressing real-world problems while integrating subjects across the curriculum, Project Based leraning a learning approach that requires learners make a "bridge" that connects a variety of subject matter. Through this path, learners can see knowledge holistically. Moreover, Project Based Learning is an in-depth investigation on a topic of the real world, it would be valuable for the attention and effort of learners (The George LucasEducational Foundation: 2005).

Global SchoolNet (2000) reported the results of the study AutoDesk Foundation of the characteristics of Project Based Learning. The results of the research shows that the Project Based Learning is a learning approach that has the following characteristics: 1) learners make decisions about a framework; 2) the problems or challenges posed to the students; 3) learners to design a process to determine a solution to the problems or challenges posed; 4) learners collaboratively responsible for accessing and managing information to solve the problem; 5) the evaluation process is run continuously; 6) learners regularly to reflect on the activities that have been run, 7) the last product of learning activity will be evaluated qualitatively; 8) learning situation is very tolerant to errors and changes. 
Based on those opinions, it can be said that the Project Based Learning approach developed by the schools of philosophy of constructivism in learning. Constructivism develops a learning atmosphere that requires learners to construct their own knowledge (Bell, 1995: 28). Project-based learning is an instructional approach that gives freedom to the learners to plan learning activities, carry out collaborative projects, and ultimately produce work products that can be presented to others.

Project Based Learning syntax as developed by The George Lucas Educational Foundation (2005) are: 1) Start With the Essential Question; 2) Design a Plan for the Project; 3) Create a Schedule; 4) Monitor the Students and the Progress of the Project; 5) Assess the Outcome; 6.) Evaluate the Experience.

On the Project Based Learningmodel, teachers act as facilitators for students to obtain answers to questions guide. Whereas in the "conventional" classroom the teacher is regarded as someone who is the most master of the material and hence all information is given directly to the learners. In Project Based Learning class, learners are accustomed to working collaboratively, the assessment is done authentically, and learning resources can be greatly expanded. This is in contrast to the "conventional" classes accustomed to individual classroom situations, the more dominant judgments on the outcome aspect of the process, and the learning resources tend to be stagnant. Adjustments can be made by the teacher in the classroom so that the syntax of the projectbased learning model can be applied to students with problems slow learner.

\section{LEARNING DESIGN OF SLOW LEARNER USING THE PROJECT BASED LEARNING MODELS}

Educational experts have a view that slow learner better to study in regular schools. This is understandable because the slow learner has little difference from normal children in their intellectual development. Slow learner placement in regular schooling can have a positive effect, both for the slow learner itself and for normal children in the regular school. Slow learner learn to interact with normal children, increase participation in groups, and learn to adjust to social life. In addition, the normal student can change the view and eliminate the negative view of disabled children (Arjmandnia and Kakabaraee, 2011: 89).

Based on definition the slow learner and learning strategies described earlier, it can be concluded that the learning strategy of slow learner is the most important and effective way to help slow learner to learn to achieve certain learning objectives, so the teacher became a teacher in planning and organizing slow learners activities. In planning and implementing slow learner learning 
strategies, a teacher needs to pay attention to the slow learnerabilities differently from other normal students.

Based on learning strategies for all children presented by Hidayat (2009: 5-6), teachers should use learning strategies that are based on the diversity of learning ability of each children. In this case, appropriate learning strategies for slow learner in inclusive schools can be applied by adjusting the learning abilities of slow learner with goals, time allocation, rewards, tasks, and assistance in the learning process.

In choosing the right learning strategy for slow learner, a teacher needs to consider several aspects. Hamzah B. Uno and Nurdin Mohamad (2011: 4) argue that in general, the selection of learning strategies based on: 1) the formulation of learning objectives; 2) analysis of needs and characteristics of students generated; and 3) types of learning materials. The third component is further adapted to media and learning resources are available and may be used (B. Uno and Nurdin Hamzah Mohamad, 2011: 4).

So that it can take an idea that electoral considerations learning strategies for slow learner include: 1) learning objectives; 2) learning materials; 3) the characteristics and needs of slow learner; 4) professional ability of teachers; 5) time allocation; 6) availability of media and props; 7) classroom and school environment or educational institutions; and 8) other considerations related to learning strategies.

Learning strategies component in this idea in terms of the components of learning strategies according to Walter Dick and Carrey (Uno and Nurdin Hamzah Mohamad B., 2011: 21-26), which suggests that there are five components of learning strategies, including: 1) the introduction of learning activities; 2) delivery information; 3) student participation; 4) learningassessment; and 5) follow-up activities.

Selection of project based learning model is most appropriate based on consideration of the selection of learning strategies for slow learner. Project based learning model syntax can be also modified in accordance with the components of learning strategies by Walter Dick and Carrey who have been outlined. Selection of this model for slow learner based on the theory of Bruner known as discovery learning (study found). According to Dahar (in Trianto, 2010: 56), trying to find the solution of the problem as well as the accompanying knowledge, producing knowledge that is really meaningful. Students are encouraged to learn through activities and experiences as well as interactions. Learning is carried out in groups with a maximum of 3 students heterogeneously. The role of teachers in learning activities is as a facilitator and companion in the form of team teaching. This design aims to address the diversity in the classroom between normal students and slow learner, so that slow learners will experience social experiences that will spur delays and foster 
self-esteem. It also deals with peer tutor during learning process with a project based learning models takes place.

Theproject-based learning model design for slow learner are :

1) The preliminary activities include the provision of perception, the delivery of learning objectives, checking the prerequisite skills, create a chart principal material, delivering an essential question in accordance with therealworldand the reality relevancy topic for students.

2) The core activities include delivery material starts from that material most importantly assisted by various media adapting the submitted material (tables, graphics, pictures, videos, concrete visuals, etc.), teachers forming groups of 3 heterogeneous students, the teacher assigns group tasks to be completed together (can be observations, experiments, or questions), students are given the freedom to looking for sources of information around it, the teacher determines the project completion deadline in one lesson, the teacher in the form of team teaching guidance and assessment during the learning process.

3) The closing activities include providing rewards for the group with the best results, the assessment carried out during the learning process and the results of group projects and group presentations, students and teachers to reflect.

4) Follow-up activities include house assignment and motivation.

\section{CONCLUSION}

Based on the exposure that has been described, the use of project-based learningmodelsin accordance with the component for slow learners, especially on a regular elementary school that consists of a wide range of students both normal students and slow learners. With the election of a strategy plan that can be adapted to the classroom conditions, the teacher can accommodate students various abilities. The use of project-based learning in this study is also expected to address the problems experienced by slow learner include: 1) have low achievement; 2) have low memory; 3 ) pay less attention; 4) has a slower learning speed compared to his classmates; 5) require more stimulus to perform simple tasks;and 6) having problems of adaptation and social relations in the classroom. In this case the teacher must have a partner as an additional companion (team teaching).

First, the strategy model of project-based learning, slow learner will be encouraged with a group system, teachers have to prepare a special assessment rubric for slow learner that academic achievement can be measured according to his ability without neglecting the development of learning along with her friends. 
Secondly, by learning the project the child will remember longer due to the information he or she gained based on direct experience.

Thirdly, with this model the child will focus on joint projects and coordinate with his group's friends to solve projects provided by the teacher, this little by little will reduce the problem of less attention to slow learner.

Fourth, the learning strategy is slow learner was also helped by discussion and tutor peers, so although initially slow, with the assistance of teachers and willingness friend groups to cooperate would in turn make the child lamb early learning gradually able to cope normally.

Fifth, stimuli are given in the form of concrete media prepared by the teacher.

The last problem, with this model the slow learner will do social interaction that requires him to be actively involved during the learning, it is necessary the participation of friends who are active to invite him to participate, so slow learner will have good social skills as well.

Thus the model of project-based learning can be used as a selection model that can be modified in the design of learning strategies to cope with slow learner in elementary school.

\section{REFERENCES}

Ana Lisdiana. (2012). "Prinsip Pengembangan Atensi pada Anak Lamban Belajar".Modul Materi Pokok Program Diklat Kompetensi Pengembangan Fungsi Kognisi pada Anak Lamban Belajar bagi Guru di Sekolah Inklusi Jenjang Lanjut. Bandung: Kementerian Pendidikan dan Kebudayaan Badan Pengembangan Sumber Daya Manusia Pendidikan dan Penjaminan Mutu Pendidikan (BPSDMP PMP) Pusat Pengembangan dan Pemberdayaan Pendidik dan Tenaga Kependidikan Taman Kanak-Kanak dan Pendidikan Luar Biasa (PPPPTK TK dan PLB).

Arjmandnia, Ali Akbar dan Keivan Kakabaraee. (2011). "The Investigation of Parents"e Attitude Toward Inclusive Education for Slow Learners" International Journal on New Trends in Education and Their ImplicationsOctober, November, December 2011 Volume: 2 Issue: 4. Hlm. 88-95. Artikel disampaikan dalam The 2nd International Conference on New Trends in Education and their Implications - ICONTE, 27- 29 April 2011, Antalya - TURKEY. Dipulikasikan www.ijonte.org.

Hamzah B. Uno. (2006). Orientasi Baru dalam Psikologi Pembelajaran.Jakata: Bumi Aksara.

Hamzah B. Uno dan Nurdin Mohamad. (2011). Belajar dengan Pendekatan PAILKEM: Pembelajaran Aktif, Inovatif, Lingkungan, Kreatif, Efektif, Menarik. Jakarta: Bumi Aksara.

Hidayat. (2009). Model dan Strategi Pembelajaran ABK dalam Setting Pendidikan Inklusif. Workshop "Pengenalan \& Identifikasi Anak Berkebutuhan Khusus (ABK) \& Strategi Pembelajarannya” Balikpapan 25 Oktober 2009. Balikpapan: Tempat Terapi untuk Anak HARAPAN KU, Ruko Kimia Farma Klandasan Lantai 2, dan Parents Support Group (PSG).

Malik, Najman Iqbal, Ghazala Rehman, dan Rubina Hanif. (2012). Effect of Academic Interventions on the Developmental Skills of Slow Learners. Pakistan Journal of Psychological Research 2012, Vol. 27, No. 1.Hlm. 135-151. 
Mumpuniarti. (2007). Pendekatan Pembelajaran bagi Anak Hambatan Mental. Yogyakarta: Kanwa Publisher.

Munawir Yusuf. (2005). Pendidikan Bagi Anak dengan Problema Belajar. Jakarta: Departemen Pendidikan Nasional Direktorat Jenderal Pendidikan Tinggi Direktorat Ketenagaan.

Nani Triani dan Amir. (2013). Pendidikan Anak Berkebutuhan Khusus Lamban Belajar(Slow Learner). Jakarta: Luxima.

Peraturan Menteri Pendidikan Nasional Republik Indonesia No. 70 Tahun 2009 tentang Pendidikan Inklusif Bagi Peserta Didik yang Memiliki Kelainan dan Memiliki Potensi Kecerdasan dan/atau Bakat Istimewa.

Pichla, Tami, Jackie Gracey, dan Karen Currie. (2006). Teaching All Students Staff Guide to Accommodations and Modifications.Huron Intermediate School District.

Reddy, G. Lokanadha, R. Ramar, dan A. Kusuma. (2006). Slow Learners: Their Psychology and Instruction. New Delhi: Discovery Publishing House.

Stubbs, Sue. (2006). Pendidikan Inklusif Ketika Hanya Ada Sedikit Sumber (Alih bahasa: Susi Septaviana R.). Bandung: Jurusan Pendidikan Luar Biasa UPI.

Sugihartono, dkk. (2007). Psikologi Pendidikan. Yogyakarta: UNY Press.

Sunaryo. (2009). Manajemen Pendidikan Inklusif Makalah Jurusan PLB. Bandung: UPI.

Trianto. (2011). Mendesain Model Pembelajaran Inovatif-Progresif: Konsep, Landasan, dan Implikasinya pada Kurikulum Tingkat Satuan Pendidikan (KTSP). Jakarta: Kencana.

Yachya Hasyim. (2013). Pendidikan Inklusif di SMK Negeri 2 Malang. Jurnal Kebijakan dan Pengembangan Pendidikan Volume 1, Nomor 2, Juli 2013Hlm.112-121. 